TECHNICAL TRANSACTIONS 8/2019

ENVIRONMENTAL ENGINEERING

DOI: $10.4467 / 2353737$ XCT.19.084.10863 SUBMISSION OF THE FINAL VERSION: 2/07/2019

\author{
Tomasz Ściężor (D) orcid.org/0000-0001-6158-6074 \\ sciezor@vistula.pk.edu.pl \\ Faculty of the Environmental Engineering, Cracow University of Technology
}

\title{
LIGHT POLLUTION AS AN ENVIRONMENTAL HAZARD
}

ZANIECZYSZCZENIE ŚWIETLNE JAKO ZAGROŻENIE ŚRODOWISKOWE

\begin{abstract}
Light pollution is one of the most widespread but at the same time least noticeable environmental hazards resulting from human activity. It is defined as disturbing the nocturnal environment with light emitted by anthropogenic sources. Light pollution is described as the glare, the trespass, and the sky glow resulting from the scattering of artificial light in the atmosphere. The paper analyses the impact of these three categories on the environment. The results of the long-term research on this problem are presented. It was found that the largest impact on the environment, both direct by the glare and indirect by the sky glow, result from lamps with spherical shields and LED advertising billboards. The possible influence of light pollution on the eutrophication of reservoirs was also researched.
\end{abstract}

Keywords: light pollution, glare, sky glow, eutrophication

\section{Streszczenie}

Zanieczyszczenie świetlne jest jednym z najpowszechniejszych, lecz jednocześnie najmniej zauważalnych zagrożeń środowiskowych. Jest ono rozumiane jako zaburzanie nocnego środowiska naturalnego światłem emitowanym przez źródła antropogeniczne. Przejawia się poprzez: olśnienie, zaświecanie oraz lunę świetlną, powstającą wskutek rozpraszania sztucznego światla w atmosferze. Przedstawiono wplyw wymienionych kategorii zanieczyszczenia świetlnego na środowisko naturalne. Zaprezentowano wyniki wlasnych badań tego zagadnienia. Stwierdzono, że największy wplyw, zarówno bezpośredni poprzez olśnienie, jak też pośredni, poprzez łunę świetlną, mają lampy z kulistymi osłonami oraz reklamowe tablice LED. Zbadano również możliwy wplyw zanieczyszczenia świetlnego na eutrofizację zbiorników wodnych.

Słowa kluczowe: zanieczyszczenie świetlne, olśnienie, łuna świetlna, eutrofizacja 


\section{Introduction}

Light pollution, known also as photopollution, is one of the more burdensome and, at the same time, one of the most unnoticed environmental hazards. Usually, it is defined as the nuisance of artificial lighting caused by an excess of light coming from improperly designed light sources. However, there are many other more or less detailed definitions. The phenomenon was described for the first time by astronomers in the mid-1970s as light pollution $[4,40]$, defined only as the brightening of the night sky due to artificial lighting. At this time, the impact of light pollution on ecosystems had already been noticed, and in the 1980s, the notion of photopollution was introduced as the degradation of the natural environment by artificial lighting [39].

\section{General concept of light pollution}

\subsection{Forms of light pollution}

According to the classification introduced in 1988 by the International Dark-Sky Association [13], light pollution may occur in the following forms:

- The gl a r e when the light source is directly visible and the contrast between it and the surroundings causes disturbance to the nocturnal vision of living organisms is one such form of light pollution. Examples are brightly lit ski slopes in winter, street lighting, and especially various types of illuminated advertising installations, mainly LED billboards rapidly changing their brightness;

- Tres p a s, treated as a violation of property boundaries, constitutes another form of light pollution. It occurs when the light source illuminates not only the dedicated area, but also the surrounding area. A typical example is the light of exterior street lamps illuminating the interiors of flats through the unprotected windows. Another example may be lamps intended to illuminate roads leading through the National Parks and other protected areas illuminating the surroundings and, in doing so, disturbing the local nocturnal ecosystems;

- Grouping of light is the form of light pollution in which the number of light sources in a given area exceeds the needs. This phenomenon often occurs in tourist areas, because the overlapping illumination coming from brightly glowing lamps is often treated as a decorative element. Such grouping of lamps also constitutes sources of light pollution in the previously mentioned categories. In urban areas, this kind of light pollution sometimes occurs in parks or university campuses. However, it can also be found in the vicinity of recreation centres located near or even inside the National Parks, reserves and other protected areas. This type of light pollution is especially visible in the case of lighting of sports facilities - sports fields, ski slopes, etc.;

- Sky glow is a form of light pollution resulting from the dispersion of artificial light on atmospheric aerosols. This is the most widespread category of light pollution as such 
dispersed light even reaches areas where none of the previously mentioned categories of light pollution are present. The sources of sky glow are improperly shielded lamp filaments or wrongly inclined lamp holders. Every single such light induces a local sky glow effect, which is important particularly in National Parks, reserves and other protected areas. However, it should be emphasised that exceptionally strong sources of this kind of light pollution are city glows, which have an impact upon and disturb even distant nocturnal ecosystems.

\subsection{The scale of the problem}

The negative impact of artificial lighting on the environment had already been noticed as early as the nineteenth century $[11,26]$. However, until the second half of the twentieth century, it seemed that this effect was minimal and limited only to certain specific environments [24].

Starting from 1950s, the rapid development of urbanisation, as well as the emergence of inexpensive sources of light, made it difficult to find areas of natural nocturnal darkness in densely populated areas on Earth. The main problem has become the sky glow, caused by the uncontrolled emission of light to the sky [38]. Satellite images show that the main such lightpolluted areas are the eastern states of the USA, Central and Western Europe and Japan. Analysis of archival measurements of the brightness of the night sky led to the conclusion that from the early 1990s, only Białostocczyzna (NE Poland) and the Bieszczady Mountains (SE Poland) show no increase in this quantity among the researched areas of Poland. In other cases, especially in large cities, a rapid increase in the sky glow surface brightness has been observed since the end of the 1990s [36]. Recently, Kyba et al. have shown a worldwide increase in brightness and lit area using VIIRS DNB data [20]. Until the middle of the twentieth century, it was believed that the only disadvantageous effect of the sky glow was its interference with astronomical observations. As a result, it was mainly astronomers who were interested in this phenomenon; of course, they only researched the glow of the cloudless sky. However, the glow of an overcast sky in the presence of light pollution sources is much brighter so, in this case, it has a significant environmental impact. This aspect of light pollution has only recently received attention $[18$, 35]. Analysis of the Light Pollution Atlas [9] and VIIRS satellite data [32] combined with the results of measurements made by the Light Pollution Monitoring Laboratory at Cracow University of Technology [35, 36] leads to the thesis that approx. $85 \%$ of Poland's surface is threatened by light pollution in the form of sky glow. In these areas, the luminance of a clear and cloudless sky exceeds the natural level of $0.21 \mathrm{mcd} / \mathrm{m}^{2}$. About $7 \%$ of Poland's surface is light polluted to a high extend with sky luminance exceeding $1.09 \mathrm{mcd} / \mathrm{m}^{2}$, which is over five times the natural level. Ground illumination from such a bright sky significantly exceeds the natural luminance caused by a quarter moon $\left(0.63 \mathrm{mcd} / \mathrm{m}^{2}\right)$ [38]. The most light-polluted areas in Poland are primarily the Silesian agglomeration, the surroundings of Gdańsk-Sopot-Gdynia, Łódź, Warszawa and Kraków, but there is also light pollution in the surroundings of each smaller town. Extending the previously accepted categorisation of light polluted areas [36], it can be concluded that the following areas belong to individual categories: A - large, industrialised cities (e.g. Kraków, Warszawa), B - medium or small cities in industrialised areas (e.g. Lublin, Szczecin, 
Niepołomice), C - medium-sized or small towns in medium-industrial areas or distant suburbs of large cities (e.g. distant suburbs of Lublin, Szczecin or Elbląg), D - medium or small towns in poorly industrialised areas (e.g. Krosno, Białystok), E - uninhabited or sparsely populated areas, located in non-industrialised areas (e.g. Bieszczady, Polesie Lubelskie, Puszcza Augustowska). The most important factor here is not the population, but its density, which should be associated with the effect of grouping the light sources and the superposition of the light coming from them. It seems that up to a population density of around 200 inhabitants $/ \mathrm{km}^{2}$, the impact of surface light sources on the brightness of the sky glow is negligibly small [38].

\subsection{The environmental impact of light pollution}

Among the many negative phenomena associated with the described problem, one can mention, in particular, the disturbance of nocturnal migrations, naturally guided by such sources of light as the moon or the stars of some constellations $[1,7,30]$. Migration disorder may consist of confusion through surface light sources misidentified as the moon, as well as blinding birds by bright light sources causing degradation to the nocturnal adaptation of their eyes. Probably even the glows of cities they pass prevent the identification of constellations of stars known to birds.

Birds are often victims of collisions with bright, illuminated windows [5]. This is especially true for office buildings, often built with glass technology. Such a bright glass wall blinds birds at night and confuses them. As part of the FLAP program [10] during each of the three-month migration seasons of 1993-1995, more than 5,000 birds from 158 species, who were victims of such collisions, were collected in the Toronto (Canada) office district, of which 64 species are on the list of endangered species. It is estimated that every year, at least one million night migrating birds perish in this city.

Artificial lighting also disturbs the reproductive cycles of many animals, mainly amphibians such as frogs and salamanders, as well as insects [28]. This negative effect was also found among mammals, including lemurs [21]. This poorly researched negative impact of light pollution directly affects night ecosystems, causing in particular, an increase in the rate of the extinction of certain species. Night lighting, both direct as well as through the sky glow, often disturbs the hunter-victim balance, for example, by extending the period of activity of migratory falcons into the night [23]. Other examples of the negative effects of light pollution are found in the ecosystems of reservoirs [25], where the artificial lighting of the water surface affects the vertical migration of zooplankton. This is the reason for its deficit in reservoir surface layers, just as occurs during the full moon [15]. In the case of the constant artificial lighting of the water surface, both direct through local lighting, as well as through the sky glow of nearby cities, zooplankton always avoids feeding in the subsurface layers of the reservoir; this could cause the growth of phytoplankton and, as a result, eutrophication [38]. It was also found that artificial light at night changes the daytime behaviour of certain species of fish [17].

The health implications of light pollution should also be considered [29]. Night lighting inhibits the production of melatonin in the human body which leads to sleep disorders. This, in turn, increases the risk of developing various types of diseases, both psychological (depression) and somatic (including cancer). 


\subsection{Sources of light pollution}

The causes of light pollution are all improperly constructed light sources, most often street, park and residential lamps $[2,8,35]$. In many cases, the problem is not so much the kind of light source or its brightness as the construction of the cover or inclination of the shield to the plane of the horizon. Older models of street lamps with a convex cover of the light source which, in addition to illuminating a dedicated object (road, pavement, parking), also send a large part of the luminous flux above the horizon. This in turn causes not only dazzling of animals and people, but also contributes to the local sky glow. Nowadays, it is recommended to use lamps with a flat cover. However, even such a solution can be a source of sky glow when the lamp shield is not parallel with the line of the horizon.

Extreme negative examples of lighting are lamps with ball-shaped covers and other decorative lamps, often found in parks and housing estates. These lamps direct most of their light sideways and upwards. At the same time, the opaque base of the cover casts a shadow on the ground, resulting in insufficient lighting of the surface under the lamp. Sometimes, often for decorative purposes, sets of several such covered lamps are created, forming a composite lamp. Such lamp, although correctly illuminating the surface, significantly increases the glare effect and also contributes very much to the sky glow. Sometimes, reflected street lamps are used. In this case, the light is directed upward to a mirror, which then reflects the light to the ground. The advantage of this kind of lighting is the lack of a dazzling effect. However, unfortunately, a large proportion of the light stream often bypasses the mirror resulting in a significant contribution to the sky glow.

Other types of light pollution sources are advertising boards (billboards), which can be both illumined externally and self-illuminated (LED boards) [22]. In the first case, light pollution is generated by models with bottom lighting, often with individual reflectors. In this case, light, both reflected from the board as well as passing it, contributes to the sky glow. LED boards, often rapidly changing in their brightness, cause glare in addition to contributing to the sky glow. This not only constitutes a threat for drivers, but is also the cause of disturbance to the neighbouring night ecosystems.

It should be noted that illumination of monuments also often contributes to an increase in brightness of the sky glow [31].

\section{Results of the measurements}

\subsection{Measuring instruments}

The measurements of light intensity were performed using the Sonopan L-52 high-sensitivity lux meter. The lux meter has four sensitivity ranges: 1-2000 lx, 0.1-200 lx, 0.01-20 lx and $0.001-2 \mathrm{~lx}$. The experimentally determined accuracy of measurements for these ranges was 3, 0.3, 0.03 and $0.003 \mathrm{~lx}$, respectively. Measurements of illuminance from distant sources were made using a diaphragm enabling the isolation of such sources from the environment. 
The sky glow is the extend object like comets, nebulae or Milky Way. Since the light from any extended object is spread out over some area of the sky, astronomers measure their surface brightness. The surface brightness is a measure of brightness per area on the sky. Measurements of the sky glow surface brightness $\left(S_{a}\right)$ were made using specialised sky quality meters (SQM), giving the results in units of surface brightness commonly used in astronomy: magnitude per square arc second ( $\left.\mathrm{mag} / \operatorname{arcsec}^{2}\right)$ [12]. This is a logarithmic and inverse scale, i.e. higher $S_{a}$ values mean darker sky, based on the human perception of the brightness of a luminous surface. There is no direct equivalent of these units in the SI system; however, to a certain extent they can be converted to the $\mathrm{cd} / \mathrm{m}^{2}$ units of luminance or $\mathrm{mcd} / \mathrm{m}^{2}$ in low light. The commonly used formula for conversion of these units is [6]:

$$
\left[\mathrm{cd} / \mathrm{m}^{2}\right]=108930 \cdot 10^{\wedge}\left(-0.4 \cdot\left[\mathrm{mag} / \operatorname{arcsec}^{2}\right]\right)
$$

The accuracy of the SQM guaranteed by the manufacturer is in the order of $0.1 \mathrm{mag} / \mathrm{arcsec}^{2}$. However, the tests performed showed a $S_{a}$ reading stability of $0.02 \mathrm{mag} / \operatorname{arcsec}^{2}$ under stable atmospheric conditions.

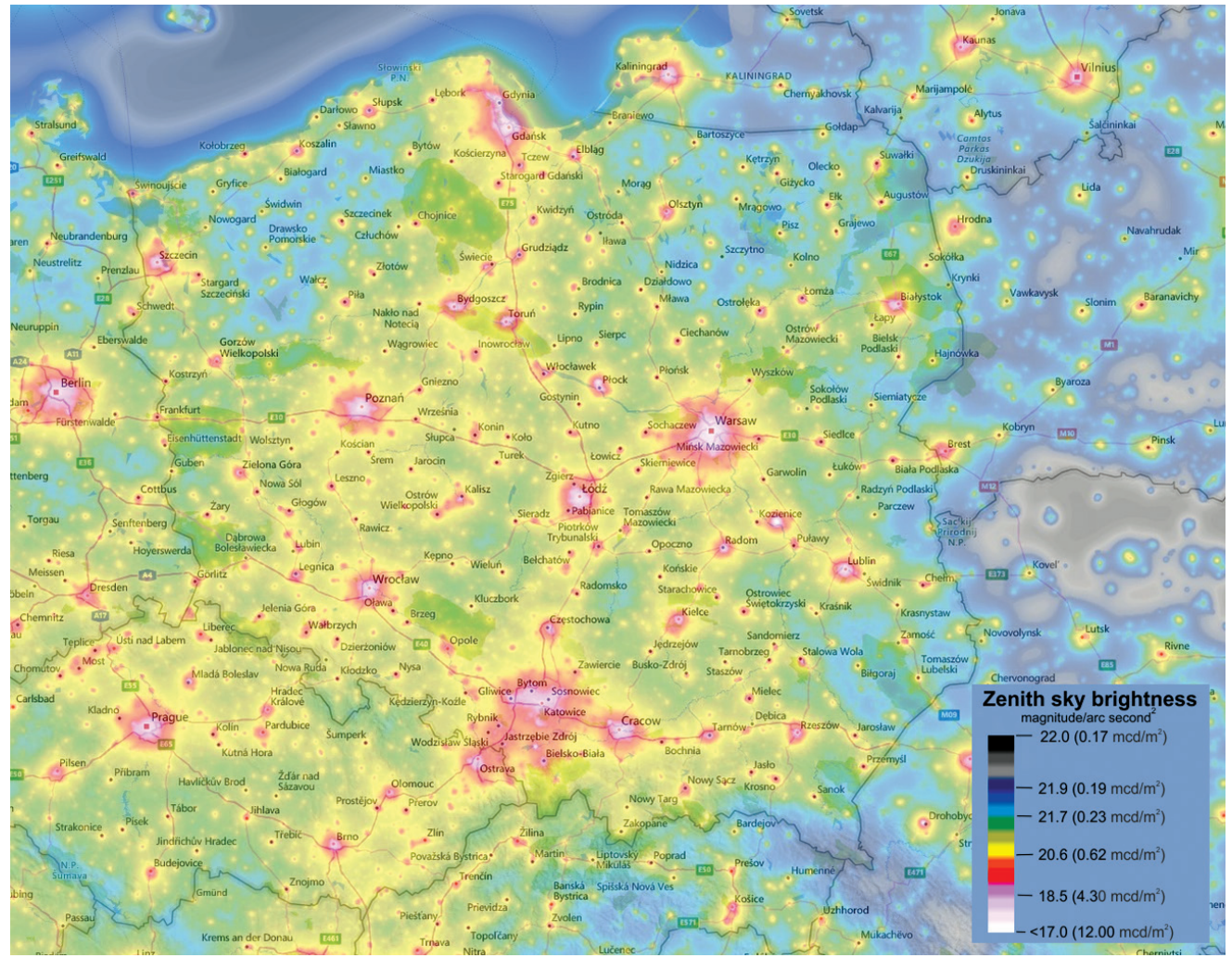

Fig. 1. Satellite map of the zenith sky brightness for the cloudless nights for Poland in 2015; the colours correspond to the modelled night sky surface brightness expressed in the astronomical units mag/arcsec $c^{2}$ and also in the SI units mcd $/ \mathrm{m}^{2}$ (VIIRS/DMSP Earth Observation Group, NOAA National Geophysical Data Center, https://www.lightpollutionmap.info) 
It should be noted that there is also a new method for nocturnal light providing spatially resolved full-spectrum radiance over the full solid angle using an all-sky camera [14] and it is planned for use in future research.

\subsection{Researched cases}

\subsubsection{Direct lighting by artificial light sources}

Measurements of illuminance of the ground as a function of distance from different types of lamps (Fig. 2) were made in three directions: towards the illuminated object (front), in the direction perpendicular to the previous direction (sideways) and in the opposite direction to the illuminated object (backlight). For some types of lamps, measurements were also taken vertically upwards, at a height of approx. $10 \mathrm{~m}$ above the lamp.

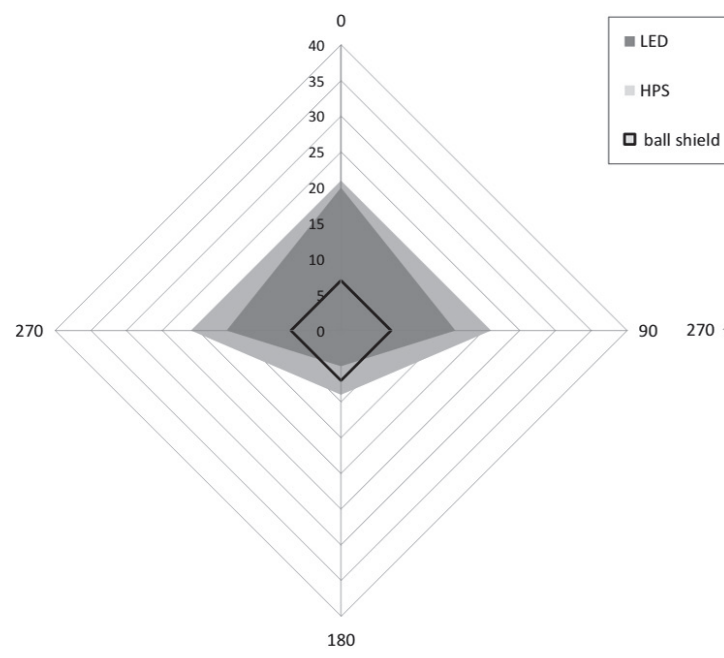

$5 \mathrm{Ix}$ range

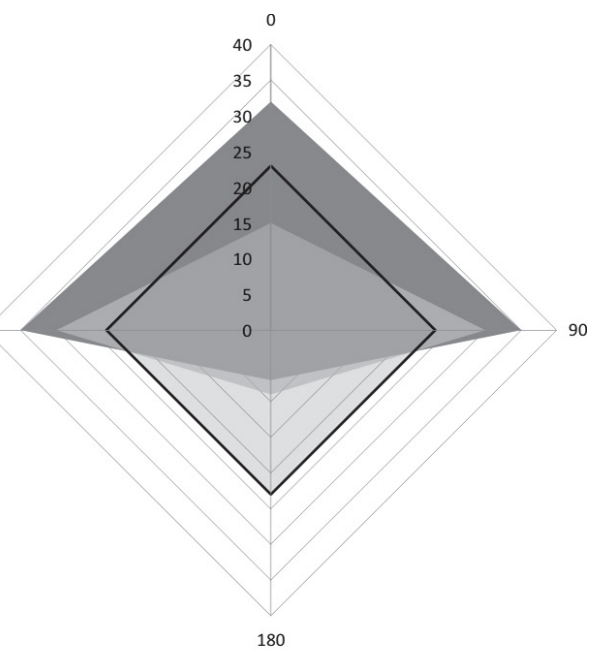

$1 \mathrm{~lx}$ range

Fig. 2. Illuminance range spatial distribution (at the $5 \mathrm{~lx}$ level, on the left and at the $1 \mathrm{~lx}$ level, on the right) around several types of lamps - estate lamps with a transparent and white ball shields, street high pressure sodium lamps

(HPS), street LED lamps; distance from the lamps is given in metres, the four cardinal directions are given in

degrees, where 0 denotes the direction of the illuminated street and 180 denotes the opposite direction

In the case of a lamp with a transparent ball-shaped cover, the distribution of illumination around the lamp and above it turns out to be largely isotropic with the exception being a deficit in the illumination of the ground directly under the lamp. This effect is related to the shadow of the cover base on the ground. The maximum illuminance, approx. 10 lux, occurs at a distance of $5 \mathrm{~m}$ from the lamp. Illuminance from these kinds of lamps drops to a level of less than $0.2 \mathrm{~lx}$ at a distance of approx. $15 \mathrm{~m}$. This is a value close to that of a full moon, so these lamps should not pose a threat to the near-surface areas of surrounding ecosystems. Moreover, they are seen from distances exceeding a dozen or so metres at low altitudes above the horizon. However, 
considering that around $70 \%$ of the light coming from these kinds of lamps is directed above the horizon, they are one of the most significant artificial sources of light disturbing the ecosystems of flying animals. In particular, in the Ojców National Park and in Orawa, the concentration of various species of moths and bats hunting for them is observed around the street lamps, which is a significant violation of the hunter-victim balance [33].

Similar considerations apply to lamps with spherical translucent white covers. The only difference to the previously described lamps is that there is practically no shadow area under such lamps.

Measurements of illumination from high-pressure sodium lamps (HPS) and modern LED lamps showed its highest value in the axis of the illuminated street. This is, of course, consistent with the intended purpose of this kinds of lamps. Illumination in the direction of illuminated streets falls below 5 lux at a distance of $20 \mathrm{~m}$ from the lamp. This means that the road is properly illuminated across the whole of its width. Illumination in the perpendicular, sideways direction also reaches a limit value of 5 lux at a distance of about $20 \mathrm{~m}$, which means that such spaced lamps should correctly illuminate the street. In the opposite direction, to the illuminated object, the level of backlight from the HPS lamps decreases to $5 \mathrm{~lx}$ at a distance of $10 \mathrm{~m}$ and only $5 \mathrm{~m}$ for LED lamps. From a distance of $7 \mathrm{~m}$, the illumination from LED lamps ceases to be measurable.

The illuminance from a single house at a distance of $60 \mathrm{~m}$ is equal to $0.06 \mathrm{~lx}$, from a single shining window at a distance of $20 \mathrm{~m}$ it is $0.08 \mathrm{~lx}$, from a shopping centre at $2 \mathrm{~km}$ it is $0.018 \mathrm{~lx}$, and at a distance of $600 \mathrm{~m}$ it is $0.03 \mathrm{~lx}$, while from an isolated housing estate at a distance of $2 \mathrm{~km}$ it is $0.2 \mathrm{~lx}$. Therefore, illumination in these cases is small, only in the latter case is it comparable with the maximum illuminance from a full moon $(0.2 \mathrm{~lx})$. Due to the fact that such distant sources of light are seen by ground-based living organisms at a low altitude above the horizon, they are effectively obscured by terrain and vegetation, and in this case, their direct impact on ecosystems should be considered to be insignificant. Such light sources, however, have an impact on the behaviour of bats, birds and insects active at night.

Much more threatening sources of light pollution in this category are advertising light boards, in particular LED boards with quickly changing brightness. Measurements show that at a distance of $12 \mathrm{~m}$ from this type of billboards, the illuminance often changes from $65 \mathrm{~lx}$ to $280 \mathrm{~lx}$ within a fraction of a second. Sometimes, illuminance changes even in the range from $15 \mathrm{~lx}$ to as much as $330 \mathrm{~lx}$, which constitutes a more than twentyfold increase. In this case, the effect of glare is particularly important. It should also be noted that in this case, the maximum illuminance exceeds that of a full moon by a few orders of magnitude reaching a value similar to that from the setting sun on a cloudless day.

\subsubsection{Illumination of the Earth's surface by the night sky glow}

The measurements of the sky surface brightness and the ground illumination made on three positions enabled the determination of a strictly linear relationship between these two factors [16]. This enables estimation of the ground illumination even if only the $S_{a}$ values are known. 
Measurements of the surface brightness $S_{a}$ of a clear and cloudless night sky revealed that the illumination of the ground through artificial light scattered in the atmosphere, even in a large city, does not exceed $0.01 \mathrm{~lx}$. Such lighting should not directly affect the ecosystems. However, the surface brightness of such sky especially in the presence of particulate matter in winter, is comparable to the sky surface brightness at dusk. This, of course, can disturb the circadian rhythms of many organisms, including humans, by affecting their biological clocks [38].

The measurements of the sky surface brightness as a function of the degree of cloudiness were made in 2010-2016 in different environments (Fig. 3). They showed a clear positive correlation between these values. In the case of large cities, the surface brightness of the overcast sky reaches $16 \mathrm{mag} / \mathrm{arcsec}^{2}$ and the corresponding ground illuminance exceeds $0.2 \mathrm{~lx}$. This value is significantly greater than the measured ground illuminance by a full moon (0.1-0.2 lx), as well as the value of $0.1 \mathrm{~lx}$ given in the literature for our latitudes [3], and even is close to the value of $0.3 \mathrm{~lx}$, which is given for tropical areas [19]. In the presence of snow cover, the sky surface brightness reaches a value close to that measured about an hour after sunset. Such illumination undoubtedly affects ecosystems, especially in the case of organisms which have a life rhythm regulated by the light of the moon. The yearly statistics of the sky surface brightness measured on moonless nights showed that in the centre of Kraków, as much as $38 \%$ of such nights is brighter than during a full moon period. In large estates and on the outskirts of the city, this value is $14-25 \%$ and $10 \%$, respectively. It should be remembered that the moon is almost a point source of light, and furthermore, its elevation changes over

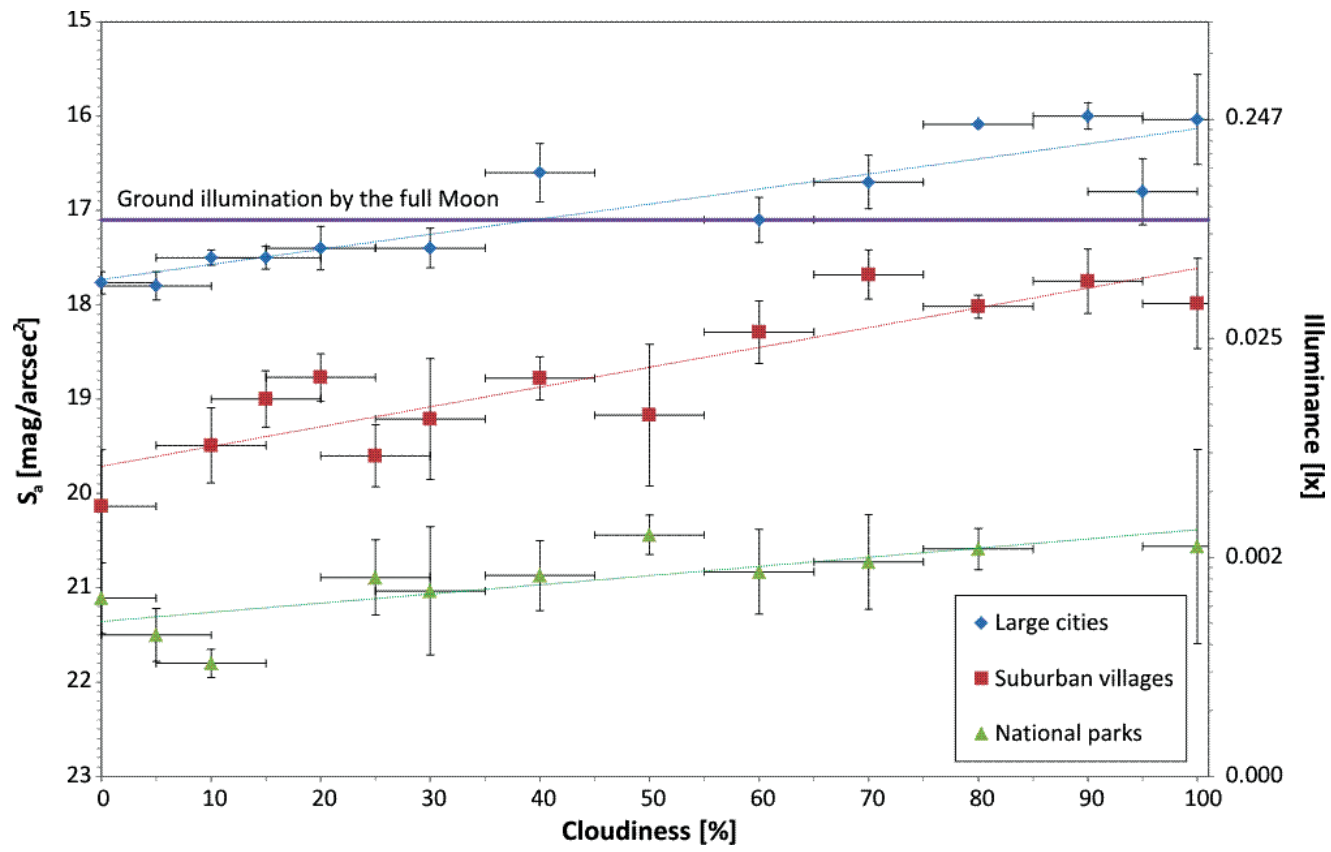

Fig. 3. The night sky surface brightness $\left(S_{a}\right)$ and ground illuminance as a function of estimated cloudiness for three different environments; the horizontal line indicates the sky surface brightness giving the ground illuminance equal to that provided by a full moon 
the course of the night, but the sky glow is visible all night, turning it into 'dusk'. This effect is not strictly related to the size of the settlement unit or its population, but rather to the density of light sources and thus, the density of the population. The sky surface brightness measured in the cities of Bielsko-Biała, Wadowice and Zakopane sometimes exceeds even that measured in Kraków [34]. In each case, the range of the 'light island', defined as the range of the measurable brightening of the sky at its zenith in comparison with the surroundings, reaches a distance of around $3 \mathrm{~km}$ from the border of the settlement unit.

\subsubsection{The impact of sky glow on the eutrophication of reservoirs}

The impact of the night-time lighting of the water surface on the reproduction and mobility of zooplankton is observed in literature [15].

In 2014-2016, measurements of the sky surface brightness were performed at the water intake of the Municipal Water and Sewerage Company in Kraków (MPWiK) on the Dobczyce Reservoir. These measurements enabled the analysis of the impact of the night sky surface brightness on the values of water quality indicators, measured at this position. The averaging of the night sky surface brightness on a time interval containing the local midnight, i.e. from 11:00 pm to 1:00 am, enabled the elimination of the effect of the variable length of twilight during the year.

Weekly reports from MPWiK give the values of the following water quality indicators for samples collected at three different depths $(3,10$ and $15 \mathrm{~m})$ : temperature, turbidity, $\mathrm{pH}$, dissolved oxygen, silica, dissolved phosphates, total phosphorus, Kieldahl nitrogen, BOD5 (biochemical oxygen demand), COD (chemical oxygen demand), suspension, conductivity, chlorophyll, phytoplankton and zooplankton (total) and the saprobicindex. A clear periodicity of about 30 days, repetitive in each research year, is observable with regard to the following indicators: concentrations of phosphates, total phosphorus, and especially chlorophyll $a$ and an abundance of phytoplankton and zooplankton. This periodicity is clearly correlated with changes in the sky brightness associated with the phases of the moon. It should be noted that values of these last mentioned indicators are directly related to the content of phytoplankton in water.

In the case of the Dobczyce Reservoir, the surface brightness of the night sky reaches values similar to that of the period of nautical twilight $\left(S_{a}=16.6 \mathrm{mag} / \mathrm{arcsec}^{2}\right)$. It was the cause for research of the correlations between the chlorophyll $a$ content and the night sky surface brightness of the night sky in 2014-2015 (Fig. 4). Due to the different frequency of measurements of both quantities, monthly averages were analysed. Only the vegetation months were taken into account, i.e. those in which temperatures enabled the development of phytoplankton: seven months in 2014 and five months in 2015.

The calculated Spearman's rank correlation coefficients between the chlorophyll $a$ content and the night sky surface brightness were -0.964 in $2014,-0.900$ in 2015 , and -0.909 for both years in total. As the quantity of analysed series of data was small, the critical values calculated with the use of randomisation tests [27] were used to assess the significance of these correlation coefficients. A one-sided permutation test was used. The correlation coefficient 

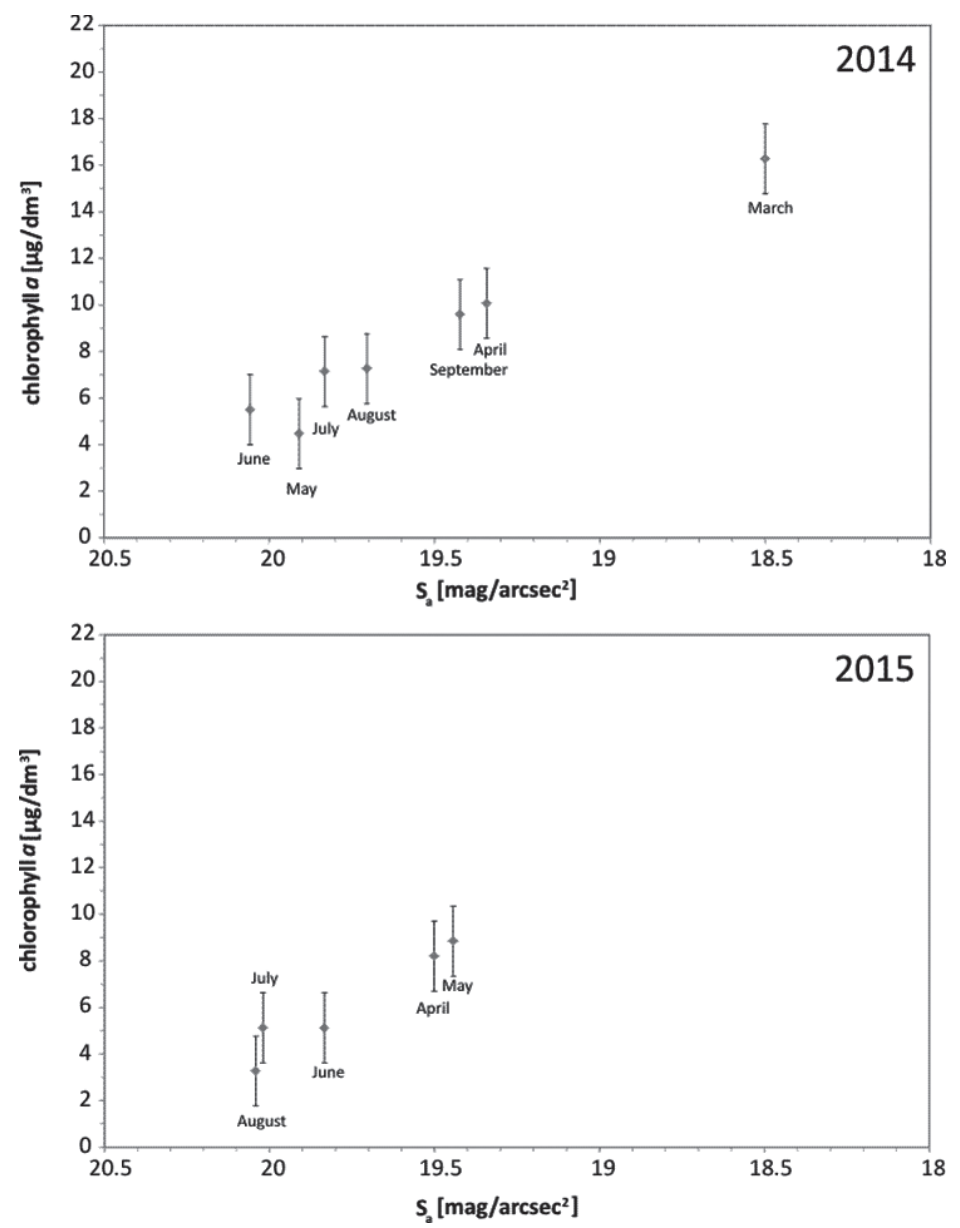

Fig. 4. Average monthly concentration of chlorophyll $a$ in the surface layer of the Dobczyce Reservoir ( $3 \mathrm{~m}$ under the surface of the water) vs. the night sky surface brightness $\left(S_{a}\right)$ in 2014 and in 2015

was equal to the critical value for the significance level $\alpha=0.0025$ in 2014 and for $\alpha=0.05$ in 2015. For both years together, the correlation coefficient was higher than 0.846 , which is the critical value for the significance level $\alpha=0.0005$. This means that the determined high correlations are significant, confirming the thesis of the impact of the night sky brightness on the chlorophyll a content. This is additionally confirmed by the impact of water turbidity on the correlation level observed in 2014 [37].

\section{Summary and conclusions}

The presented research shows that artificial, improperly shielded light sources should have only a small direct impact on terrestrial ecosystems. However, they cause disturbance of the hunter-victim balance in the case of pterofauna ecosystems. The problem concerns, 
in particular, lamps with spherical shields. In this case, approx. $70 \%$ of the light is emitted above the horizon line, with the dominant vertical direction. The same light sources generate the night sky glow to a large extent. Such glow, especially in cities, has a major impact on ecosystems, both by creating the effect of unceasing twilight, and by illuminating the ground at night in conditions with an overcast sky. Moreover, the sky glow also affects the city's surroundings, directly disturbing the night ecosystems in the adjacent areas, mainly because the permanent full-moon light level masks the natural cycle of the moon. An example of such ecosystems is reservoirs, where both night lighting of the water surface by the light sources located on the shore (or, for example, the dam shaft), as well as by the glow coming from surrounding villages, can lead to eutrophication and, as a result, water quality deterioration.

To minimise the negative impact of artificial night lighting on the environment, it is necessary to:

- avoid the placement of various types of advertising boards, especially LED with variable brightness, near protected areas;

- install street lamps at such distances from the protected areas that outside the dedicated area, the ground illumination does not exceed that which comes from a full moon. The minimum distance, regardless of the type of lamp, can be specified at approx. $35-40 \mathrm{~m}$;

- use appropriate shields which direct light only to the dedicated area - the impact of the direct light of such a lamp on the surroundings will then be minimised, and the brightness of the sky glow will also be reduced, and this particularly applies to cities located near protected areas.

These activities, in addition to having a positive impact on the environment, will give measurable economic benefits.

Further studies of the described problem are planned, in particular, with regard to the effect of the spectrum or colour of nocturnal light on the environment.

I would like to thank the employees of the Municipal Water and Sewerage Company in Kraków (MPWiK), especially to Mr. Jacek Stasik for the supervision of continuous measurements of the night sky brightness on the water intake in Dobczyce and to Mr. Tadeusz Bochnia for sharing weekly reports on water quality.

\section{References}

[1] Allen J.A., Destruction of birds by light-houses, Bulletin of the Nuttall Ornithological Club 5, 1880, 131-138.

[2] Bartnicki M., Źródła światła, nowe możliwości, nowe zagrożenia, Zeszyty Naukowe Politechniki Białostockiej, Architektura 20, 2007, 15-24.

[3] Insect Photoperiodism, ed. Beck S.D. Academic Press, 9, 1980.

[4] Berry R.L., Light Pollution in Southern Ontario, Journal of the Royal Astronomical Society of Canada 70, 1976, 97-115.

[5] Chepesiuk R., Missing the Dark: Health Effects of Light Pollution, Environ Health Perspect. 117(1), 2009, A20-A27. 
[6] Crawford D.L., Photometry: terminology and units in the lighting and astronomical sciences, The Observatory, 117, 1997, 14-18.

[7] Foster J.J., Smolka J., Nilsson D.E., Dacke M., How animals follow the stars, Proceedings of the Royal Society B: Biological Sciences 285(1871), 2018, 2017.2322.

[8] Guide on the Limitation of the Effects of Obtrusive Light from Outdoor Lighting Installations, Commission Internationale de l'Eclarage, Technical Report No. 150:2003.

[9] Cinzano P., Falchi F., Elvidge C., Recent progression a second world atlas of the night-sky brightness. LPTRAN/LPDART realistic models, tomography of light pollution, accurate validation methods and extended satellite data analysis, [in:] StarLight: A Common Heritage, eds. C. Marín, J. Jafari, StarLight Initiative. Instituto de Astrofísica de Canarias, Canary Islands, 2007, 385-400.

[10] Fatal Light Awareness Program [online], http://www.flap.org (access: 29.03.2019).

[11] Guillemin A., Le Ciel, L.Hachette, Paris 1866, 384-385.

[12] Hänel A., Posch T., Ribas S.J., Aubé M., Duriscoe D., Jechow A., Kollath Z., Lolkema D.E., Moore C., Schmidt N., Spoelstra H., Wuchterl G., Kyba C.C.M., Measuring night sky brightness: methods and challenges, Journal of Quantitative Spectroscopy and Radiative Transfer 205, 2018, 278-290.

[13] IDA 1988, International Dark-Sky Association [online], http://www.darksky.org (access: 29.03.2019).

[14] Jechow A., Kyba C.C.M., Hölker F., Beyond All-Sky: Assessing Ecological Light Pollution Using Multi-Spectral Full-Sphere Fisheye Lens Imaging, Journal of Imaging 5(4), 2019, 46.

[15] Jung, J., Hojnowski C., Jenkins H., Ortiz A., Brinkley C., Cadish L., Evans A., Kissinger P., Ordal L., Osipova S., Smith A., Vredeveld B., Hodge T., Kohler S., Rodenhouse N., Moore M., Diel vertical migration of zooplankton in Lake Baikal and its relationship to body size, [in:] Ecosystems and Natural Resources of Mountain Regions. Proceedings of the first international symposium on Lake Baikal: The current state of the surface and underground hydrosphere in mountainous areas, eds. A.I. Smirnov, L. R. Izmest'eva, Nauka, Novosibirsk 2004, 131-140.

[16] Kubala M., Ściężor T., Oświetlenie gruntu przez zanieczyszczone świetlnie nocne niebo, [in:] Interdyscyplinarne zagadnienia winżynierii iochronieśrodowiska 2, ed. T.M. Traczewska, Oficyna Wydawnicza Politechniki Wrocławskiej, Wrocław 2012, 301-308.

[17] Kurvers R. H. J. M., Drägestein J., Hölker F., Jechow A., Krause J., Bierbach D., Artificial Light at Night Affects Emergence from a Refuge and Space Use in Guppies, Scientific Reports 8, 2018, 14131.

[18] Kyba C.C.M., Ruhtz T., Fischer J., Hölker F., Cloud Coverage Acts as an Amplifier for Ecological Light Pollution in Urban Ecosystems, PLoS ONE 6(3), 2011, e17307.

[19] Kyba C.C.M, Mohar A., Posch T., How bright is moonlight?, Astronomy \& Geophysics 58(1), 2017, 1.31-1.32.

[20] Kyba C.C.M., Kuester T., Sánchez de Miguel A., Baugh K., Jechow A., Hölker F., Bennie J., Elvidge C.D., Gaston K.J., Guanter L., Artificially lit surface of Earth at night increasing in radiance and extent, Science Advances 3(11), 2017, e1701528.

[21] Le Tallec T., Perret M., Théry M., Light Pollution Modifies the Expression of Daily Rhythms and Behavior Patterns in a Nocturnal Primate, PLoS One 8(11), 2013, e79250. 
[22] Lim H.S., Ngarambe J., Kim J.T., Kim G., The Reality of Light Pollution: A Field Survey for the Determination of Lighting Environmental Management Zones in South Korea, Sustainability 10(374), 2017, 1-11.

[23] Marconnot B., Comportement de chasse nocturne du Faucon pelerin Falco peregrinus à Belfort, Ornithos 10(5), 2003, 207-211.

[24] Massey P., Gronwall C., Pilachowski C.A., The spectrum of the Kitt Peak Night Sky, Publications of the Astronomical Society of the Pacific 102(655), 1990, 1046-1051.

[25] Moore M.V., Pierce S.M., Walsh H.M., Kvalvik S.K., Lim J.D., Urban light pollution alters the diel vertical migration of Daphnia, Verhandlungen des Internationalen Verein Limnologie, 27, 2000, 1-4.

[26] Astronomy for Amateurs, ed. J.A.W. Oliver, Longmans, Green 1888, 295.

[27] Ramsey P.H., Critical Values for Spearman's Rank Order Correlation. Journal of Educational Statistics 14(3), 1989, 245-253.

[28] Ecological Consequences of Artificial Night Lighting, eds. C. Rich, T. Longcore, Island Press 2006.

[29] Skwarło-Sońta K., Skażenie świattem: co dziś wiemy o jego wptywie na funkcjonowanie organizmu człowieka?, KOSMOS - Problemy Nauk Biologicznych, 4(309), 2015, 579-587.

[30] Squires W.A., Hanson H.E. The destruction of birds at the lighthouses on the coast of California, Condor 20, 1918, 6-10.

[31] Skarżyński K., Iluminacja obiektów architektonicznych a zanieczyszczenie środowiska świattem, KOSMOS - Problemy Nauk Biologicznych 4(309), 2015, 553-562.

[32] Stare J., Light Pollution Map. Earth Observation Group, NOAA National Geophysical Data Center [online] https://www.lightpollutionmap.info (access: 29.03.2019).

[33] Stone E.L., Harris S., Jones G. Impacts of artificial lighting on bats: A review of challenges and solutions, Mammalian Biology - Zeitschrift für Saugetierkunde 80, 2015, 213-219.

[34] Ściężor T., Kubala M., Kaszowski W., Light Pollution of the Mountain Areas in Poland, Archives of Environmental Protection 38(4), 2012, 59-69.

[35] Ściężor T., Kubala M., Wplyw chmur niskich i wysokich na bliskie i dalekie zanieczyszczenie świetlne, Czasopismo Techniczne 2-Ś/2012, 253-260.

[36] Ściężor T., A new astronomical method for determining the brightness of the night sky and its application to study long-term changes in the level of light pollution, Monthly Notices of the Royal Astronomical Society 435(1), 2013, 303-310.

[37] Ściężor T., Balcerzak W., Wptyw zanieczyszczenia świetlnego na eutrofizację Zbiornika Dobczyckiego, KOSMOS - Problemy Nauk Biologicznych 4(309), 2015, 599-610.

[38] Ściężor T., Naturalneiantropogeniczne czynnikitunyświetlnejnocnego nieba, Wydawnictwo Politechniki Krakowskiej, Kraków 2018.

[39] Verheijen F.J., Photopollution: artificial light optic spatial control systems fail to cope with. Incidents, causation, remedies, Experimental Biology 44(1), 1985, 1-18.

[40] Walker M.F., Light Pollution in California and Arizona, Publications of the Astronomical Society of the Pacific 85(507), 1973, 508-519.

If you want to quote this article, its proper bibliographic entry is as follow: Ściężor T., Light pollution as an environmental 